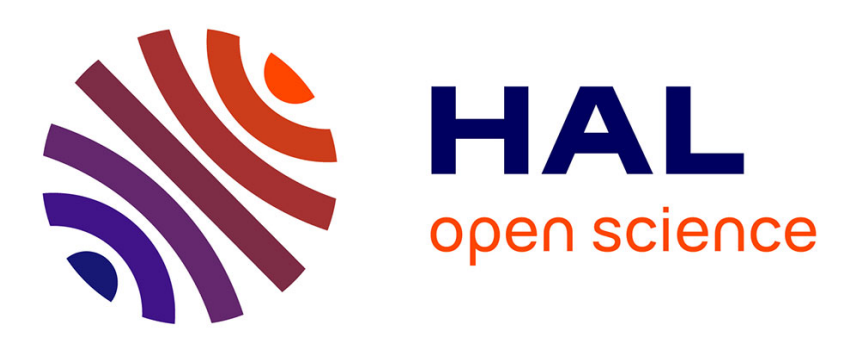

\title{
One-Step Synthesis of Sodium Trimetaphosphate (Na3P3O9) from Sodium Chloride and Orthophosphoric Acid
}

Doan Pham Minh, Jocelyn Ramaroson, Ange Nzihou, Patrick Sharrock

\section{- To cite this version:}

Doan Pham Minh, Jocelyn Ramaroson, Ange Nzihou, Patrick Sharrock. One-Step Synthesis of Sodium Trimetaphosphate (Na3P3O9) from Sodium Chloride and Orthophosphoric Acid. Industrial and engineering chemistry research, 2012, 51 (10), p.3851-3854. 10.1021/ie201085b . hal-01632407

\section{HAL Id: hal-01632407 \\ https://hal.science/hal-01632407}

Submitted on 20 Oct 2018

HAL is a multi-disciplinary open access archive for the deposit and dissemination of scientific research documents, whether they are published or not. The documents may come from teaching and research institutions in France or abroad, or from public or private research centers.
L'archive ouverte pluridisciplinaire HAL, est destinée au dépôt et à la diffusion de documents scientifiques de niveau recherche, publiés ou non, émanant des établissements d'enseignement et de recherche français ou étrangers, des laboratoires publics ou privés. 


\title{
One-Step Synthesis of Sodium Trimetaphosphate $\left(\mathrm{Na}_{3} \mathrm{P}_{3} \mathrm{O}_{9}\right)$ from Sodium Chloride and Orthophosphoric Acid
}

\author{
Doan Pham Minh, ${ }^{\dagger} * *$ Jocelyn Ramaroson, ${ }^{\dagger}$ Ange Nzihou, ${ }^{\dagger}$ and Patrick Sharrock ${ }^{\ddagger}$ \\ ${ }^{\dagger}$ Université de Toulouse, Mines Albi, CNRS, Centre RAPSODEE, Campus Jarlard, F-81013 Albi Cedex 09, France \\ ${ }^{\ddagger}$ IUT de Castres, Avenue Georges Pompidou, 81108 Castres, France
}

\begin{abstract}
One-step thermal synthesis of sodium trimetaphosphate (STM) from sodium chloride and 85 wt \% orthophosphoric acid as starting materials was investigated. The reaction temperature and volume-mean diameter of sodium chloride influenced strongly the elimination of chloride and the selectivity in STM. STM of high quality (99\%) was obtained at $600{ }^{\circ} \mathrm{C}$ from fine powder of sodium chloride. Hydrochloric acid was the only byproduct of the reaction.
\end{abstract}

\section{INTRODUCTION}

Polyphosphates, and particularly sodium trimetaphosphate (STM), could be used in different applications such as water treatment, metal surface treatment, detergent, food additives, etc. ${ }^{1-5}$ STM is one of the most popular cross-linkers used in food chemistry. ${ }^{6-9}$ Papo et al. found that STM is a good dispersant for kaolin suspensions, which are important raw materials in advanced ceramic processing. ${ }^{1}$ In multistage flash seawater distillation, STM was found to be a good antiscale agent. ${ }^{10}$ In addition, STM is the starting material for the synthesis of all other metal trimetaphosphates. ${ }^{11}$

STM is industrially synthesized following the process of Thilo and Grunze in which sodium dihydrogen phosphate $\left(\mathrm{NaH}_{2} \mathrm{PO}_{4}\right)$ was heated to $500{ }^{\circ} \mathrm{C}$ for $5 \mathrm{~h}^{12-14}$ Solid product is then cooled down to room temperature and STM is obtained after a recrystallization step. However, $\mathrm{NaH}_{2} \mathrm{PO}_{4}$ is a relatively expensive product because it is synthesized by the electrolysis of aqueous solution of sodium chloride to produce sodium hydroxide, following by neutralization of sodium hydroxide with orthophosphoric acid. The industrial production of STM can be summarized by following equations:

$$
\begin{aligned}
& 2 \mathrm{NaCl}+2 \mathrm{H}_{2} \mathrm{O} \rightarrow 2 \mathrm{NaOH}+\mathrm{Cl}_{2}+\mathrm{H}_{2} \\
& \mathrm{NaOH}+\mathrm{H}_{3} \mathrm{PO}_{4} \rightarrow \mathrm{NaH}_{2} \mathrm{PO}_{4}+\mathrm{H}_{2} \mathrm{O} \\
& 3 \mathrm{NaH}_{2} \mathrm{PO}_{4} \rightarrow \mathrm{Na}_{3} \mathrm{P}_{3} \mathrm{O}_{9}+3 \mathrm{H}_{2} \mathrm{O}
\end{aligned}
$$

Therefore, from sodium chloride and orthophosphoric acid as starting reactants, STM is obtained after four steps: electrolysis, neutralization, thermal synthesis, and recrystallization, taking into account the first two steps for the synthesis of $\mathrm{NaH}_{2} \mathrm{PO}_{4}$. Gaseous $\mathrm{H}_{2}$ and $\mathrm{Cl}_{2}$ are two byproducts.

This work aims to investigate the one-step thermal synthesis of STM from sodium chloride and orthophosphoric acid as starting reactants. These reactants were chosen because of their good availability and low cost for an eventual real application.

\section{MATERIALS AND METHODS}

Sodium chloride powder with the volume-mean diameter $\left(d_{\mathrm{NaCl}}\right)$ of $375 \mu \mathrm{m}$ (labeled SC1) from Acros Organics and 85 wt \% orthophosphoric acid from Merck were used. Crushing this $\mathrm{SC} 1$ for $10 \mathrm{~h}$ in a rotary porcelain jar led to the formation of a finer powder with $78 \mu \mathrm{m} d_{\mathrm{NaCl}}$ (labeled SC2). The particle size of sodium chloride powder was measured by laser scattering using dry dispersion technique in a Mastersizer 2000 (Malvern Instruments Ltd., Malvern, U.K.). The measurement was carried out at 3.5 bar of air pressure.

The reaction was carried out in a quartz reactor composed of a cylinder-shaped tube with gas input and output, a $65 \mathrm{~mL}$ crucible where the reaction will take place, and a stick for keeping the crucible fixed. The reactor was heated by a vertical furnace with a defined temperature program. For the reaction, sodium chloride $(87.5 \mathrm{mmol})$ and orthophosphoric acid (87.5 $\mathrm{mmol}$ ) were introduced into the crucible at room temperature. The reactor was heated to the reaction temperature and kept at this temperature for $120 \mathrm{~min}$. It was then freely cooled down to room temperature. During the reaction, air circulation (120 L/ h) was applied. Output gas was trapped into a wash bottle containing water or an aqueous potassium hydroxide solution.

ICP-AES (inductive coupled plasma atomic emission spectroscopy) measurements were performed on a HORIBA Jobin Yvon Ultima 2 for the analysis of elementary phosphorus and sodium. Chloride $\left(\mathrm{Cl}^{-}\right)$and phosphorus-containing anions were analyzed using a Dionex ionic chromatography apparatus equipped with a conductivity detector and a Dionex IonPac AS $19(4 \times 250 \mathrm{~mm})$ column.

TGA-DSC (simultaneous thermogravimetric analysis and differential scanning calorimetry) was carried out in a TA Instruments SDTQ600 analyzer. It simultaneously measures the heat flow and weight changes associated with transitions and reactions in materials. Infrared spectroscopy (IR) was performed with a Shimadzu FTIR 8400 S spectrometer. XRD (X-ray diffraction) data was collected using a Phillips Panalytical X'pert Pro MPD diffractometer with a $\mathrm{Cu} \mathrm{K} \alpha$ (1.543 $\AA$ ) radiation source and a nickel film, which suppressed the $\mathrm{Cu} \mathrm{K} \beta$ ray. Scanning electron microscopy (SEM) was carried out using a Philips XL30 ESEM apparatus (FEI 
Company), equipped with a energy dispersive X-ray (EDX) analysis module.

\section{RESULTS AND DISCUSSION}

3.1. Thermal Reaction. The reaction between sodium chloride powder and orthophosphoric acid occurred even at room temperature, observed by the formation of hydrochloric acid, and could be illustrated in eq 4 .

$$
\mathrm{NaCl}+\mathrm{H}_{3} \mathrm{PO}_{4} \rightarrow \mathrm{Na}_{a} \mathrm{H}_{b} \mathrm{P}_{c} \mathrm{O}_{d}+\mathrm{HCl}+\mathrm{H}_{2} \mathrm{O}
$$

However, a high temperature was required for the formation of condensed phosphates. The analysis of the solid product $\left(\mathrm{Na}_{a} \mathrm{H}_{b} \mathrm{P}_{c} \mathrm{O}_{d}\right)$ by ionic chromatography showed the presence of different phosphorus-containing species: orthophosphate $\left(\mathrm{PO}_{4}{ }^{3-}\right)$, pyrophosphate $\left(\mathrm{P}_{2} \mathrm{O}_{7}{ }^{4-}\right)$, and trimetaphosphate $\left(\mathrm{P}_{3} \mathrm{O}_{9}{ }^{3-}\right)$ anions. The selectivity of a given phosphorus anion "A" $\left(S_{\mathrm{A}}\right)$ in the solid product and chloride elimination rate $\left(X_{\mathrm{Cl}}\right)$ were calculated as follows:

$$
\begin{aligned}
& S_{\mathrm{A}}=\frac{\text { quantity of phosphorus found in A form }}{\text { initial quantity of phosphorus }} \times 100 \\
& X_{\mathrm{Cl}}=\frac{\text { quantity of eliminated chloride }}{\text { initial quantity of chloride }} \times 100
\end{aligned}
$$

Table 1 shows the analysis results of solid products formed in the reaction temperature range $300-600{ }^{\circ} \mathrm{C}$, using two sodium

Table 1. Elimination of Chloride and Distribution of Phosphorus-Containing Species in Solid Products

\begin{tabular}{cccccc}
$T\left({ }^{\circ} \mathrm{C}\right)$ & $d_{\mathrm{NaCl}}(\mu \mathrm{m})$ & $X_{\mathrm{Cl}}(\%)$ & $S_{\mathrm{PO}_{4}}(\%)$ & $S_{\mathrm{P}_{2} \mathrm{O}_{7}}(\%)$ & $S_{\mathrm{P}_{3} \mathrm{O}_{9}}(\%)$ \\
300 & 375 & 76 & 5 & 5 & 51 \\
300 & 78 & 83 & 8 & 16 & 54 \\
400 & 375 & 89 & 1 & 7 & 74 \\
400 & 78 & 95 & 0 & 2 & 85 \\
500 & 375 & 90 & 0 & 5 & 80 \\
500 & 78 & 97 & 0 & 0 & 93 \\
600 & 375 & 98 & 0 & 0 & 90 \\
600 & 78 & 99 & 0 & 0 & 99 \\
\hline
\end{tabular}

chloride powders with two different volume-mean diameters of sodium chloride particles. Both the reaction temperature and the particle size of sodium chloride powder had important influences on the chloride elimination rate $\left(X_{\mathrm{Cl}}\right)$ and the selectivity in trimetaphosphate anion $\left(S_{\mathrm{P}_{3} \mathrm{O}_{9}}\right)$. The higher the reaction temperature was, the better the chloride elimination rate and the selectivity in trimetaphosphate anion were. However, the reaction temperature was limited at $600{ }^{\circ} \mathrm{C}$ because a higher temperature could lead to the transformation of STM into Graham's salt product by melting at ca. $627^{\circ} \mathrm{C} .{ }^{15}$ Low contents of $\mathrm{PO}_{4}{ }^{3-}$ and $\mathrm{P}_{2} \mathrm{O}_{7}{ }^{4-}$ anions were observed at 300 and $400{ }^{\circ} \mathrm{C}$. This means that dehydration reactions of orthophosphate and pyrophosphate occurred already at these temperatures. At higher reaction temperatures, these anions disappeared to form $\mathrm{P}_{3} \mathrm{O}_{9}{ }^{3-}$ anion. The formation of $\mathrm{P}_{3} \mathrm{O}_{9}{ }^{3-}$ anion increased continuously with the increase of the reaction temperature and reached up to $99 \%$ at $600{ }^{\circ} \mathrm{C}$ with fine sodium chloride powder. In parallel, the chloride elimination rate increased, too.

At a given reaction temperature, the chloride elimination rate was higher with crushed sodium chloride powder $\left(d_{\mathrm{NaCl}}=78\right.$ $\mu \mathrm{m})$ than with initial sodium chloride powder $\left(d_{\mathrm{NaCl}}=375\right.$ $\mu \mathrm{m})$. The effect of the particle size of sodium chloride was minor at lower temperatures and became more important at higher temperatures. The best chloride elimination rate was $99 \%$, obtained at $600{ }^{\circ} \mathrm{C}$ with SC2. The decrease of particle size of sodium chloride favored its contact with orthophosphoric acid and therefore favored the reaction. In fact, the product of the reaction, essentially STM at 500 and $600{ }^{\circ} \mathrm{C}$, existed in solid phase and could isolate the sodium chloride core from orthophosphoric acid if the initial sodium chloride particles are too big. This phenomenon is particularly important because the reaction was carried out without stirring. In spite of a high temperature of $600{ }^{\circ} \mathrm{C}$, some traces of chloride were until detected when fine sodium chloride $\left(d_{\mathrm{NaCl}}=78 \mu \mathrm{m}\right)$ powder was used. This result can be explained by the presence of a small fraction $(8 \%)$ of the particles in the range $200-316 \mu \mathrm{m}$ ) in this fine sodium chloride powder, as shown in Figure 1.

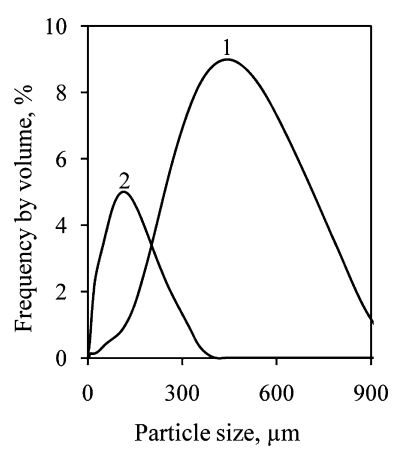

Figure 1. Distribution of particle size of sodium chloride powder before (1) and after (2) crushing.

The analysis of gaseous products trapped in wash bottle showed that only chloride was present in $\mathrm{HCl}$ form. The total quantity of chloride in gaseous and solid products reached the initial quantity of chloride used in all cases.

3.2. Characterization of the Solid Products. Ionic chromatography analysis permitted the determination of chloride elimination rate and the distribution of phosphoruscontaining species in the solid products. However, supplementary characterizations are necessary for identifying its components. We present here the characterization results obtained with the solid product of $99 \%$ chloride elimination rate and $99 \%$ selectivity in trimetaphosphate anion that is labeled Syn-STM.

Figure 2 shows XRD patterns of Syn-STM and pure STM (commercial product from Aldrich). All peaks present in the Syn-STM pattern could be attributed to STM diffraction. No other crystalline phase was found. Synthesized STM was also very well crystallized at $600{ }^{\circ} \mathrm{C}$ with a free cooling under air atmosphere.

Figure 3 compares IR spectra of Syn-STM and pure STM. Both spectra were very similar to each other, characterized by vibrations of trimetaphosphate ring in the wavenumber range from $650 \mathrm{~cm}^{-1}$ to $1400 \mathrm{~cm}^{-1}$. ${ }^{16-18}$ IR results confirmed again that STM was the only compound present in Syn-STM.

Figure 4 presents ATG-DSC analysis of Syn-STM in the temperature range $25-750{ }^{\circ} \mathrm{C}$. A mass reduction of $1.4 \%$ was recorded at $750{ }^{\circ} \mathrm{C}$ that must be due to the dehumidification and probably the elimination of the last traces of chloride remaining in Syn-STM. Two endothermic peaks were observed. The first peak at $546.4{ }^{\circ} \mathrm{C}$ could be due to the melting of an 


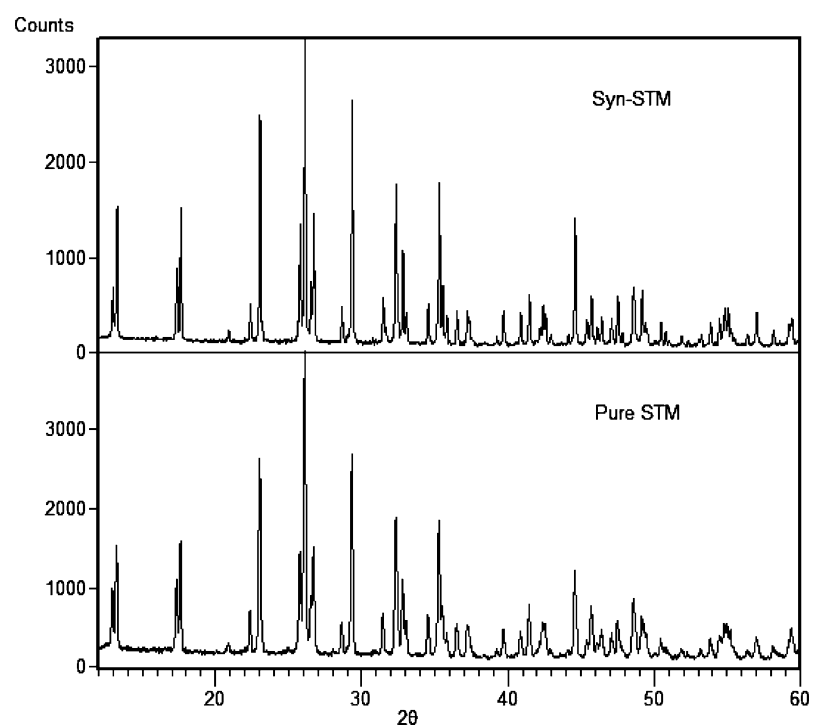

Figure 2. XRD patterns of Syn-STM and pure STM.

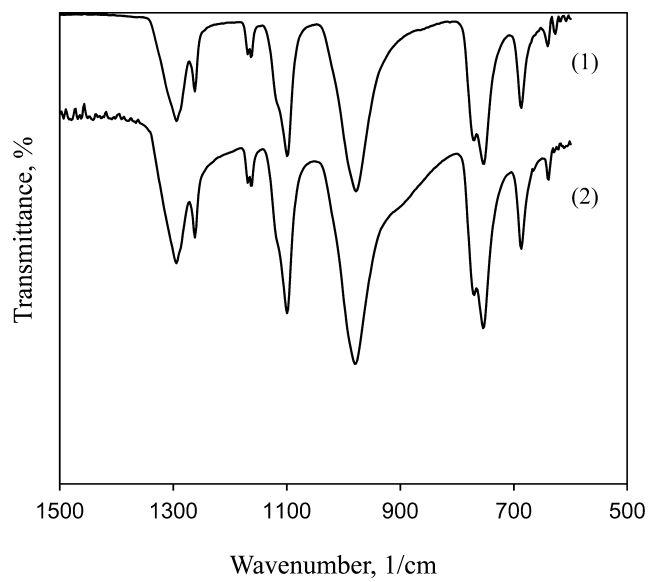

Figure 3. IR spectra of pure STM (1) and Syn-STM (2).

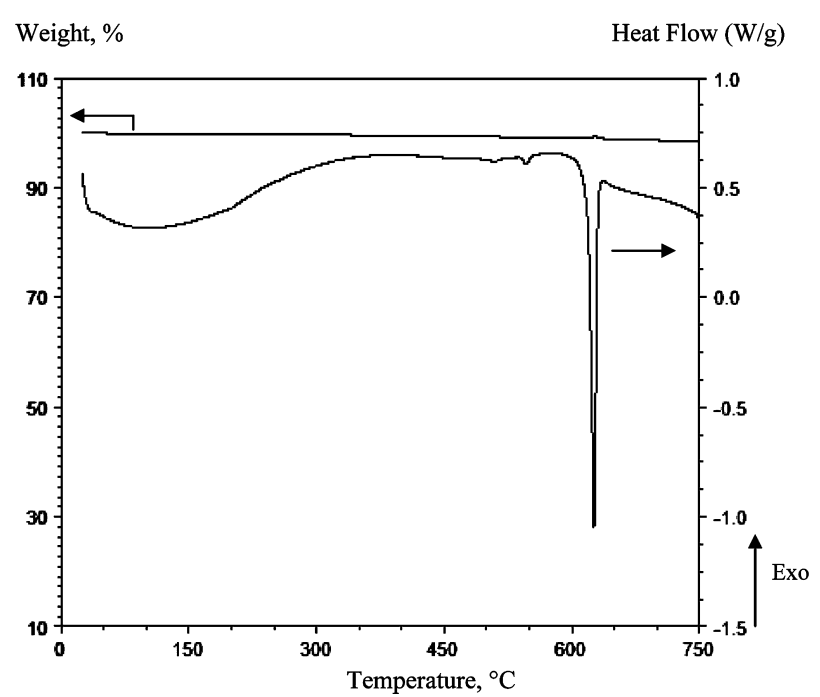

Figure 4. ATG-DSC of Syn-STM in the temperature range $25-750$ ${ }^{\circ} \mathrm{C}$. intermediate present at very low content in Syn-STM. The second peak at $626.6{ }^{\circ} \mathrm{C}$ could be attributed to the melting of STM. ${ }^{15}$ As mentioned, the reaction temperature must not exceed this melting point to avoid the transformation of STM into Graham's salt. ${ }^{15}$

SEM images of Syn-STM are shown in Figure 5. Solid product in homogeneous powder form was observed. EDX

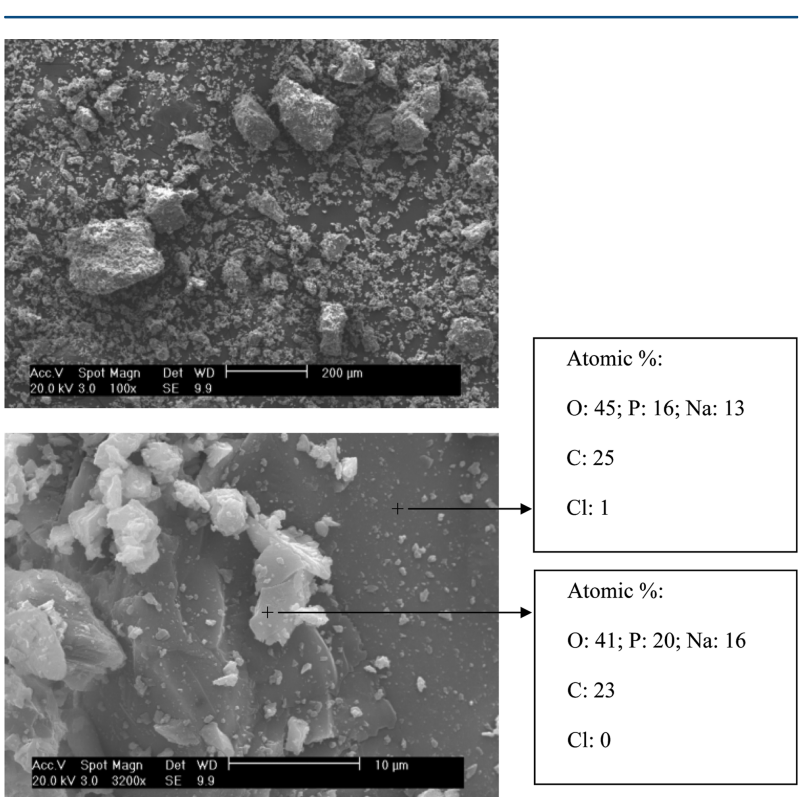

Figure 5. SEM-EDX analysis of Syn-STM.

analysis was carried out on different points of sample and showed similar results. According to the results of ionic chromatography analysis, chlorine was detected at low content while phosphorus, sodium, and oxygen were found as the main elements. Note that the presence of carbon was due to carbonic gas in the air.

\section{CONCLUSIONS}

Sodium trimetaphosphate (STM) was successfully synthesized from sodium chloride and orthophosphoric acid by one-step thermal process $\left(600{ }^{\circ} \mathrm{C}\right.$ for $\left.2 \mathrm{~h}\right)$. Using a fine sodium chloride powder of $78 \mu \mathrm{m}$ volume-mean diameter, chloride could be nearly totally eliminated (99\%) and STM of high quality (purity of 99\%) was obtained. Hydrochloric acid was the only byproduct that could be easily recovered by condensation. In comparison with the competing industrial process, the present work seems to be more economical and ecological thanks to the overcoming of three steps (electrolysis, neutralization, and recrystallization).

Future work will focus on the synthesis using finer sodium chloride powders to increase the contact of sodium chloride particles with orthophosphoric acid and therefore reduce the temperature and/or time of the reaction. The synthesis of other alkali trimetaphosphates from $\mathrm{LiCl}$ and $\mathrm{KCl}$ and orthophosphoric acid should be investigated.

\section{AUTHOR INFORMATION}

\section{Corresponding Author}

*Tel.: +33 563493258. Fax: +33 563493043. E-mail address: doan.phamminh@mines-albi.fr. 


\section{Notes}

The authors declare no competing financial interest.

\section{ACKNOWLEDGMENTS}

Dr. Nathalie Lyczko is gratefully acknowledged for her assistance in XRD analysis.

\section{REFERENCES}

(1) Papo, A.; Piani, L.; Ricceri, R. Sodium tripolyphosphate and polyphosphate as dispersing agents for kaolin suspensions: rheological characterization. Colloid. Surf., A 2002, 201, 219.

(2) Rashchi, F.; Finch, J. A. Polyphophates: A review their chemistry and application with particular reference to mineral processing. Miner. Eng. 2000, 13, 1019.

(3) Halliwell, D. J.; Mckelvie, I. D.; Hart, B. T.; Dunhill, R. H. Hydrolysis of triphosphate from detergents in a rural waste system. Water Res. 2001, 35, 448.

(4) Ferrer, J. C.; Salinas-Castillo, A.; Alonso, J. L.; Fernández de Ávila, S.; Mallavia, R. Synthesis and characterization of CdS nanocrystals stabilized in polyvinyl alcohol-sodium polyphosphate. Mater. Lett. 2009, 63, 638.

(5) Kutun, S.; Akseli, A. New elution agent, sodium trimetaphosphate, for the separation and determination of rare earths by anionexchange chromatography. J. Chromatogr., A 1999, 847, 261.

(6) Li, B. Z.; Wang, L. J.; Li, D.; Chiu, Y. L.; Zhang., Z. J.; Shi, J.; Chen., X. D.; Mao, Z. H. Physical properties and loading capacity of starch-based microparticles crosslinked with trisodium trimetaphosphate. J. Food Eng. 2009, 92, 255.

(7) Cury, B. S. F.; Klein, S. I.; Evangelista, R. C. Modeling a system of phosphated cross-linked high amylase for controlled drug release. Part 1: Synthesis and polymer characterization. React. Funct. Polym. 2008, 68, 1200.

(8) Muhammad, K.; Hussin, F.; Man, Y. C.; Ghazali, H. M.; Kennedy, J. F. Effect of $\mathrm{pH}$ on phosphorylation of sago starch. Carbohydr. Polym. 2000, 42, 85 .

(9) Lack, S.; Dulong, V.; Picton, L.; Le Cerf, D.; Condamin, E. Highresolution nuclear magnetic resonance spectroscopy studies of polysaccharides crosslinked by sodium trimetaphosphate: A proposal for the reaction mechanism. Carbohydr. Res. 2007, 342, 943.

(10) Butt, F. H.; Bou-Hassan, A. H. Performance of a polyphosphatebased scale control additive in an MSF plant of Kuwait. Desalination 1981, 36, 129.

(11) Averbuch-Pouchot, M. T.; Durif, A. Topics in Phosphate Chemistry; World Scientific: Singapore, 1996; pp 31-36.

(12) Thilo, E. H.; Grunze, H. Der Entwässerungsverlauf der Dihydrogenmonophosphate des $\mathrm{Li}, \mathrm{Na}, \mathrm{K}$, und $\mathrm{NH}_{4}$. Z. Anorg. Allg. Chem. 1955, 281, 262.

(13) Ondik, H. M. The structures of anhydrous sodium trimetaphosphate, $\mathrm{Na}_{3} \mathrm{P}_{3} \mathrm{O}_{9}$, and the monohydrate, $\mathrm{Na}_{3} \mathrm{P}_{3} \mathrm{O}_{9} \cdot \mathrm{H}_{2} \mathrm{O}$. Acta Crystallogr. 1965, 18, 226.

(14) Durif, A. The development of cyclophosphate crystal chemistry. Solid State Sci. 2005, 7, 760.

(15) Bastide, J. P.; Azzouz, L.; Germain, P. Etude de la cristallisation du trimetaphosphate de sodium vitreux. Première partie: aspect cristallochimique. Mater. Res. Bull. 1994, 29, 351.

(16) Sbai, K.; Belaaouad, S. Chemical preparation, crystal structure, thermal behavior and IR studies of barium thallium cyclotriphosphate dihydrate. J. Phys. Chem. Solid 2000, 64, 981.

(17) Nahdi, K.; Ferid, M.; Trabelsi-Ayadi, M. Chemical preparation and thermal behavior of neodymium cyclotriphosphate pentahydrate $\mathrm{NdP}_{3} \mathrm{O}_{9} \cdot 5 \mathrm{H}_{2} \mathrm{O}$ : A study by controlled rate thermal analysis (CRTA). Thermochim. Acta 2009, 487, 54.

(18) Jouini, A.; Ferid, M.; Gâcon, J. C.; Grosvalet, L.; Thozet, A.; Trabelsi-Ayadi, M. Crystal structure, vibrational spectra, and optical properties of praseodymium cyclotriphosphate $\mathrm{PrP}_{3} \mathrm{O}_{9} \cdot 3 \mathrm{H}_{2} \mathrm{O}$. Mater. Res. Bull. 2006, 41, 1370. 